\title{
Steeping and germination of wheat (Triticum aestivum L.). I. Unlocking the impact of phytate and cell wall hydrolysis on bio-accessibility of iron and zinc elements
}

\author{
Elien Lemmens ${ }^{\mathrm{a}, *}$, Niels De Brier ${ }^{\mathrm{a}, 1}$, Peter Goos ${ }^{\mathrm{b}}$, Erik Smolders ${ }^{\mathrm{c}}$, Jan A. Delcour ${ }^{\mathrm{a}}$ \\ ${ }^{a}$ Laboratory of Food Chemistry and Biochemistry, and Leuven Food Science and Nutrition Research Centre (LFoRCe), KU Leuven, Kasteelpark Arenberg 20, B-3001, Leuven, Belgium \\ ${ }^{\mathrm{b}}$ Division of Mechatronics, Biostatistics and Sensors (MeBioS), KU Leuven, Kasteelpark Arenberg 30, B-3001, Leuven, Belgium \\ ${ }^{c}$ Division of Soil and Water Management, KU Leuven, Kasteelpark Arenberg 20, B-3001, Leuven, Belgium
}

\section{A R T I C L E I N F O}

\section{Introduction}

Wheat (Triticum aestivum L.) is a major source of starch and protein and provides $20-30 \%$ of the daily caloric intake in many countries (Shewry and Hey, 2015). Wheat grains are rarely used in their intact form and typically roller milled to separate the white flour (i.e. starchy endosperm) from the bran and embryo tissues (Delcour and Hoseney, 2010). The millers' bran is a multi-layered tissue comprising, from the outside to the inside, the pericarp, seed coat, nucellar epidermis and aleurone (Barron et al., 2007).

Due to its excellent functionality, refined white flour is widely used for the production of foods such as bread and breakfast cereals, while the bran co-products are mainly used as animal feed (Delcour and Hoseney, 2010). However, whole grain food products deserve to be an important part of the human diet since there is a well-established (epidemiological) relationship between consuming whole grain food products and reducing the risk of developing diet-related disorders such as type 2 diabetes (de Munter et al., 2007), etc. These health benefits can mainly be ascribed to relatively high concentrations of dietary fibre and bioactive compounds such as B vitamins, mineral elements [for example iron (Fe) and zinc ( $\mathrm{Zn})$ ], methyl donors (for example betaine, choline and folates) and polyphenols (Fardet, 2010).

Many of these compounds are mainly concentrated in the aleurone, but typically have low bio-accessibility (i.e. availability for absorption in the human gastrointestinal tract) as they are entrapped in cells with rigid walls which withstand conventional milling processes and digestion by the human enzyme arsenal (Balk et al., 2019). The aleurone wheat cell walls are composed of arabinoxylan (AX) (65\%) esterified with ferulic acid, $\beta$-D-glucan (29\%) and minor portions of cellulose (2\%), glucomannans (2\%) and proteins (Shewry and Hey, 2015). Moreover, about $85 \%$ of wheat phosphorus (P) is stored as phytic acid (myo-inositol 1,2,3,4,5,6-hexakisphosphate). Phytic acid occurs mainly as granules embedded in protein-rich globoid structures in the aleurone cells (Raboy, 2003). It chelates divalent cations such as Fe, Zn, calcium $(\mathrm{Ca})$, manganese $(\mathrm{Mn})$, magnesium $(\mathrm{Mg})$ and copper $(\mathrm{Cu})$, result-

Abbreviations: Arabinose, ara; avDP, average degree of polymerisation; AX, arabinoxylan; ICP-MS, inductively coupled plasma mass spectrometry; Idm, initial dry matter; rpm, rotations per minute; xylose, xyl; WEAX, water extractable arabinoxylan; WUAX, water unextractable arabinoxylan. * Corresponding author.

E-mail addresses: elien.lemmens1@kuleuven.be (E. Lemmens); Niels.DeBrier@rodekruis.be (N. De Brier); peter.goos@kuleuven.be (P. Goos); erik.smolders@kuleuven.be (E. Smolders); jan.delcour@kuleuven.be (J.A. Delcour)

1 Current address: Centre for Evidence-Based Practice, Rode Kruis Vlaanderen, Motstraat 42, 2800 Mechelen, Belgium. 
ing in phytates. Unfortunately, phytates are only poorly digested or absorbed by humans due to the lack of intestinal phytase enzymes (González-Córdova et al., 2016). The result is elemental bio-accessibility of only 3-5\% (Lemmens et al., 2018).

Technologies are therefore needed to increase the mineral content and/or bio-accessibility in food products. Fortunately, while fortification approaches are expensive and not easily available to those living in underdeveloped and developing countries, certain food processing unit operations have the capability to affect the chelation of multivalent elements to phytate structures and, hence, their bio-accessibility.

Wheat germination initiates seedling growth and proceeds once adequate temperature and moisture content have been met and dormancy has been broken. Synthesis and release of hydrolytic enzymes during germination is regulated by plant hormones such as gibberellic (GA) and abscisic (ABA) acids. GA triggers the aleurone cells to synthesise and secrete hydrolytic enzymes to mobilise grain reserves that fuel the germination while ABA postpones these processes (Miransari and Smith, 2014).

Ungerminated wheat grains exhibit some endogenous phytase activity which strongly increases during the first three days of germination (Lemmens et al., 2018). Wheat $\alpha$-amylase activity increases from the first day of germination to reach a maximum after four days while endoxylanase activity increases only slowly during the first three to five days (Corder and Henry, 1989; De Backer et al., 2010). Endoxylanase hydrolyses the AX present in the aleurone and starchy endosperm cell walls and thereby makes the nutrients better available for the developing embryo (Bewley et al., 2013). However, at present, whether partial hydrolysis of cell wall material during germination suffices to release mineral elements is unknown. The increase in phytase activity during germination makes phosphate, multivalent mineral elements and myo-inositol available for plant growth and development (Greiner et al., 2000).

When used in a food system context, technologies such as wheat grain steeping and controlled germination can reasonably be expected to increase the bio-accessibility of the above named mineral elements in the human gastro-intestinal tract. Indeed, recent research showed that further hydrolysis of phytate structures during hydrothermal processing using optimal conditions for phytase action $\left(50-60^{\circ} \mathrm{C}, \mathrm{pH} 4.0,8-24 \mathrm{~h}\right)$ increased the $\mathrm{Fe}$ and $\mathrm{Zn}$ bio-accessibility in whole meal from germinated wheat to 37 and $27 \%$, respectively (Lemmens et al., 2018). However, in spite of the above work, it is not known to what extent the mineral bio-accessibility is related to either chelation to phytates and/or their entrapment in plant cells with rigid walls.

Against this background, the present study aimed to study the hydrolysis of phytate chelates and AX (the major wheat endosperm cell wall component) in relation to mineral bio-accessibility by using controlled wheat steeping and germination technologies. Moreover, the (un)germinated study samples were either milled $(<200 \mu \mathrm{m})$ or fractionated into coarse particles $(>1 \mathrm{~mm})$ to obtain a substantial fraction of intact cells. This was done to disentangle the role of cell wall integrity on mineral bio-accessibility from that of phytate breakdown. The gathered knowledge sheds light on how complex wheat matrices affect the bio-accessibility of mineral elements and offers ways to improve their accessibility during food manufacturing.

\section{Materials and methods}

\subsection{Materials}

All chemicals and reagents were of at least analytical grade and purchased from Sigma-Aldrich (Bornem, Belgium) unless otherwise specified. Winter wheat (Cellule winter wheat, harvest 2015) was kindly supplied by Limagrain (Avelgem, Belgium). A reference wheat (NIST1567) flour sample with certified element composition was ob- tained from the National Institute of Standards and Technology (Gaithersburg, MD, USA).

\subsection{Experimental design}

To investigate the impact of steeping and germination conditions on phytate and AX hydrolysis in wheat and to identify the conditions that maximise both phytate and AX hydrolysis, a two-step four-factor I-optimal response surface experimental design was developed and used. I-optimal experimental designs guarantee precise predictions and are thus ideal for process optimisation purposes. Response surface designs are intended to quantify the experimental factors' main effects, interaction effects and quadratic effects.

Here, the four experimental factors were steeping time, germination time, steeping temperature and germination temperature. Steeping times ranged from 8 to $36 \mathrm{~h}$, steeping temperatures from 15 to $40^{\circ} \mathrm{C}$, germination times from 0 to $120 \mathrm{~h}$ and germination temperatures from 15 to $30^{\circ} \mathrm{C}$.

Since wheat germination only proceeds as soon as an adequate moisture content has been reached, a linear restriction for steeping time and temperature was imposed on the factor settings in the experimental design to ensure a moisture content of at least $35 \%$ at every test. The wheat grains were steeped at various time and temperature conditions and their moisture content was measured (data not shown). This indicated that imposing the following restriction guaranteed a sufficiently large moisture content: steeping temperature $+3.9 \times$ steeping time $\geq$ 61.7.

In the experiment, 160 different factor level combinations were tested and response surface models were fit for the resulting phytate and water extractable arabinoxylan (WEAX) responses using ordinary least squares regression to identify significant $(P<0.05)$ effects. Random block effects were included in the response surface model to account for the split-plot nature of the experiment and a dummy variable was used to take into account the fact that the entire experiment was performed in two blocks. Block to block variation was expected because of the differences in the experimental set up [for example type of steeping process ( $c f r$. below), maintenance of the micro malting device and germination capacity of the grains as a function of time]. The final response surface models were obtained by using backward model selection. The model fit was evaluated based on the coefficient of determination $\left(\mathrm{R}^{2}\right)$ and the actual-by-predicted plot comparing the observed and predicted response values.

First, a response surface model was fit to explain the variation in phytate contents as a function of steeping time and temperature and germination time and temperature. Because the phytate contents were expressed as a proportion, a logit transformation was used for that response when building the model. More specifically, the dependent variable was taken to be logit (response $)=\log \left(\frac{\text { response }}{1-\text { response }}\right)$. The final model for the transformed response had a $\mathrm{R}^{2}$ value of $82 \%$.

Second, the final response surface model fit to explain the variation in WEAX content as a function of steeping time and temperature and germination time and temperature had an $\mathrm{R}^{2}$ value of $89 \%$.

\subsection{Steeping, germination and hydrothermal treatment of wheat grains}

For steeping temperatures up to $30^{\circ} \mathrm{C}$, ungerminated wheat grains (i.e. regular, untreated grains) were steeped in excess deionised water ( $900 \mathrm{~g}$ wheat for each trial in 2801 of water) in a pilot-scale micro malting system (Joe White Malting Systems, Perth, Australia). When steeping temperatures higher than $30^{\circ} \mathrm{C}$ (not possible in the micro malting system) were applied, ungerminated wheat grains were put in a 21 beaker and steeped in deionised water $[1: 10(\mathrm{w} / \mathrm{v})]$ at different study temperatures $\left(31-40^{\circ} \mathrm{C}\right)$. Depending on the steeping time (cfr. 2.2), 
steeping phases consisted of wet stages of up to $8 \mathrm{~h}$ alternated by intermediate air rest stages at $15^{\circ} \mathrm{C}$ for $6 \mathrm{~h}$ to keep the grains viable.

The imbibed grains were then germinated for $120 \mathrm{~h}$ in the pilot-scale micro malting system. Samples were taken after steeping $(0 \mathrm{~h})$ and after different times of germination (6, 12, 24, 48, 72, 96 and $120 \mathrm{~h})$.

In a next step, wheat grains steeped for $36 \mathrm{~h}$ at $15^{\circ} \mathrm{C}$ and then germinated for $48 \mathrm{~h}$ at $26^{\circ} \mathrm{C}$, were hydrothermally treated in triplicate for 8 h at $40^{\circ} \mathrm{C}$ (Loading Modell 100-800, Memmert, Schwabach, Germany) in closed Schott glass bottles to keep the moisture content constant.

The processed wheat grains were finally flash-frozen using liquid nitrogen $\left(\mathrm{N}_{2}\right)$, freeze-dried (to a moisture content of 5\%, Alpha 1-4 LD plus, Martin Christ, Analis, Namur, Belgium) and milled (IKA-mill, Staufen, Germany) into whole meal $(<200 \mu \mathrm{m})$ prior to further use in experiments.

For the in vitro digestion procedure ( $c f r$. 2.9), coarse fragments (1.0-2.0 mm) obtained by mechanically breaking (freeze-dried) grains in a Waring (Stamford, CT, USA) blender were fractionated over a set of sieves (Laboratory test sieves, Endecotts, London, UK) to select the fraction passing the $2.0 \mathrm{~mm}$ but not the $1.0 \mathrm{~mm}$ sieve.

A flow chart representing the experimental setup described in this section can be found in supplementary data (Fig. S1).

\subsection{Moisture content}

The moisture content of wheat grains was measured in triplicate according to the AACC Method 44-15A. In essence, $2.0 \mathrm{~g}$ of wheat grains were oven-dried for $16 \mathrm{~h}$ at $130^{\circ} \mathrm{C}$ and their moisture content (\%) was then determined gravimetrically.

\subsection{Phytase activity}

The phytase activity assay was executed in triplicate as described by Lemmens et al. (2018). In brief, the inorganic orthophosphate released from phytic acid as a result of phytase action was quantified colorimetrically $(400 \mathrm{~nm})$ in an aliquot of a whole meal extract ( $\mathrm{pH} 5.0$ ) using ammonium molybdate. Phytase activity will be defined as the amount of enzyme that releases $1 \mu \mathrm{mol}$ of phosphate per minute of incubation per gram dry matter $(\mathrm{dm})$ at $37^{\circ} \mathrm{C}$.

\subsection{Phytic acid content}

The phytic acid content in whole meal was determined after extraction in triplicate in $0.66 \mathrm{M} \mathrm{HCl}$ of myo-inositol phosphates as in the Megazyme (Bray, Ireland) K-Phyt assay with slight modifications essentially as in Lemmens et al. (2018). The concentration of free P in the extracts was subtracted from the total $\mathrm{P}$ concentration after subsequent breakdown of myo-inositol phosphates by phytase and alkaline phosphatase to obtain the content of bound P. The content of the latter was then divided by 0.282 in order to calculate the amount of phytate. The phytate concentration will be defined as weight $\%$ of the initial $\mathrm{dm}(\%$ of idm).

\subsection{Endoxylanase activity}

Endoxylanase activities were determined in triplicate with the Megazyme Xylazyme AX method. Whole meal $(0.50 \mathrm{~g})$ was suspended in $5.0 \mathrm{ml} 25 \mathrm{mM}$ sodium acetate buffer ( $\mathrm{pH} 5.0$ ), extracted [ $30 \mathrm{~min}$, 150 rotations per minute $\left.(\mathrm{rpm}), 7^{\circ} \mathrm{C}\right]$ and centrifuged $(10 \mathrm{~min}, 9800 \mathrm{~g}$, $7^{\circ} \mathrm{C}$ ). Next, an azurine cross-linked AX tablet (substrate) was added to $1.0 \mathrm{ml}$ of pre-incubated extract at $40^{\circ} \mathrm{C}$. The reaction was stopped after
$6 \mathrm{~h}$ of incubation $\left(40^{\circ} \mathrm{C}\right)$ by adding $10.0 \mathrm{ml} 1.00 \% \mathrm{w} / \mathrm{v}$ trishydroxymethylaminomethane. The suspension was filtered (Whatman, GE Healthcare Life Sciences, Buckinhamshire, UK) and the extinction measured at $590 \mathrm{~nm}$ against a blank obtained by incubating the extracts without a substrate tablet (Ultraspec, 2000 UV/VIS spectrophotometer, GE Healthcare, Uppsala, Sweden). To correct the obtained extinction value for colour release by the substrate tablet itself, a specific control sample was measured by incubating buffer with a substrate tablet for $6 \mathrm{~h}$. One endoxylanase activity unit is the enzyme activity which increases the extinction by 1.00 per $h$ under the conditions of the assay.

\subsection{Water extractable arabinoxylan content and its average degree of polymerisation}

Prior to analysis, endoxylanase in $0.334 \mathrm{~g}$ whole meal was inactivated by reflux with ethanol $(10 \mathrm{ml}, 80 \%)$, the whole meal was then suspended in $20.0 \mathrm{ml}$ deionised water, extracted $\left(30 \mathrm{~min}, 150 \mathrm{rpm}, 7^{\circ} \mathrm{C}\right)$ and centrifuged $\left(10 \mathrm{~min}, 1500 \mathrm{~g}, 7^{\circ} \mathrm{C}\right)$. The WEAX content was determined in triplicate by gas chromatography. In essence, carbohydrates in the extract were hydrolysed into monosaccharides by trifluoroacetic acid (4.0 M). Next, the resulting monosaccharides were reduced to alditols by sodium borohydride $(5.3 \mathrm{M})$ under alkaline conditions. The resulting alditols were derivatised to volatile alditol acetates after acetylation with acetic anhydride (99.6\%) using 1-methylimidazole (99\%) as catalyst. The WEAX content was calculated as the sum of xylose (xyl) and arabinose (ara) multiplied by 0.88 .

For determining the average degree of polymerisation (avDP) also the free ara and xyl and xyl reducing end contents in the extract were determined. When analysing the free ara and xyl contents, no acid hydrolysis was performed. For determining the xyl reducing end content, reduction was performed prior to hydrolysis. With the obtained ara and xyl contents, the avDP was calculated as follows: avDP of $\mathrm{WEAX}=\left[\left([\mathrm{ara}]_{\text {WEAX }}-[\text { ara }]_{\text {free }}\right)+\left([\mathrm{xyl}]_{\text {WEAX }}-[\mathrm{xyl}]_{\text {free }}\right)\right] /[\mathrm{xyl}]_{\text {WEAX, re }}$ ducing end.

\subsection{Iron and zinc bio-accessibility}

The mineral bio-accessibility, i.e. the amount of mineral elements that was released from the food matrix, was determined at least in triplicate with an in vitro digestion procedure essentially as in Lemmens et al. (2018). This procedure simulates the digestion process in mouth, stomach and small intestine. Mineral absorption itself was not measured in the present study. In practice, whole meal $(<200 \mu \mathrm{m})$ or coarse fragments $(1-2 \mathrm{~mm})$ were incubated with pepsin $(\mathrm{pH} 2.0)$ for $2 \mathrm{~h}$ and pancreatin ( $\mathrm{pH} 6.8$ ) for $3 \mathrm{~h}$ at $37^{\circ} \mathrm{C}$ under magnetic stirring ( $250 \mathrm{rpm}$ ). The solubilised elements were quantified with inductively coupled plasma mass spectrometry (ICP-MS) (cfr. 2.10). The elemental bio-accessibility was calculated as follows:

Mineral bio - accessibility (\%)

$=\frac{\text { mass of element in digested fraction }(\mathrm{g} \mathrm{dm})}{\text { total mass of element in wheat }(\mathrm{g} \mathrm{dm})}$
$* 100$

The difference between the Fe and $\mathrm{Zn}$ concentrations in undigested wheat samples and in the weighted average concentrations of all corresponding fractions obtained after the in vitro digestion procedure varied between 7 and 15\%.

\subsection{Elemental content}

The elemental content in the (un)germinated wheat samples and freeze-dried digested fractions thereof (cfr. 2.9) was determined at least in triplicate by ICP-MS with an Agilent 7700x (Santa Clara, CA, USA) 
as in Lemmens et al. (2018). In essence, samples $(0.05 \mathrm{~g},<200 \mu \mathrm{m})$ were digested with $1.0 \mathrm{ml}$ ultrapure $25 \% v / v \mathrm{HNO}_{3}$ and subsequently with $2.0 \mathrm{ml}$ aqua regia $(75 \% v / v$ ultrapure $\mathrm{HCl}$ and $25 \% v / v$ ultrapure $\left.\mathrm{HNO}_{3}\right)$ at $150^{\circ} \mathrm{C}$, followed by dilution with Milli-Q water $(18.2 \mathrm{M} \Omega \mathrm{cm}$ at $25^{\circ} \mathrm{C}$; Milli-Q Plus, Merck Millipore, Darmstadt, Germany) to $10.0 \mathrm{ml}$. The reported elements were recovered within $10 \%$ of the certified values of the NIST1567 wheat reference. The total concentrations of the elements in ungerminated wheat, in $\mathrm{mg} / \mathrm{kg} \mathrm{dm}$ ( \pm standard deviation, $\mathrm{n} \geq 3$ ), were 4,319 $\pm 164 \mathrm{~K} ; 3,463 \pm 132 \mathrm{P} ; 1,268 \pm 34 \mathrm{Mg} ; 465 \pm 7 \mathrm{Ca}$; $34.8 \pm 0.9 \mathrm{Fe} ; 33.7 \pm 1.2 \mathrm{Mn} ; 21.6 \pm 0.3 \mathrm{Zn}$ and $3.3 \pm 0.1 \mathrm{Cu}$ (Lemmens et al., 2018).

\subsection{Statistical analysis}

For constructing the I-optimal experimental design and for estimating the response surface models for phytate and AX breakdown, the JMP Pro 13 software (SAS Institute, Cary, NC) was used. A one-way ANOVA $(\mathrm{P}<0.05)$ with Tukey multiple comparison procedure was executed to identify significant differences between mean values of the other responses in this study.

\section{Results and discussion}

\subsection{Impact of steeping and germination of wheat grains on phytate content}

To evaluate the impact of steeping and germination conditions of wheat grains on phytate hydrolysis an I-optimal experimental design was constructed (cfr. 2.2).

The steeping time had a clear negative main effect $(P<0.001)$ on phytate content (Supplementary data, Fig. S2A). Wheat grains contain endogenous phytase which were already active during steeping. In addition, there was a quadratic effect $(\mathrm{P}=0.002)$ for the germination time, with a minimal predicted phytate content at a germination time of $120 \mathrm{~h}$ (Supplementary data, Fig. S2A). Indeed, generally, relatively long germination times are needed to lower the phytate concentration by more than $30 \%$ (Lemmens et al., 2019). The model also involved a significant quadratic effect $(\mathrm{P}=0.022)$ for germination temperature, with a minimal predicted phytate content at temperatures ranging from 22 to $26^{\circ} \mathrm{C}$ (Supplementary data, Fig. S2A). Endogenous phytase is

A

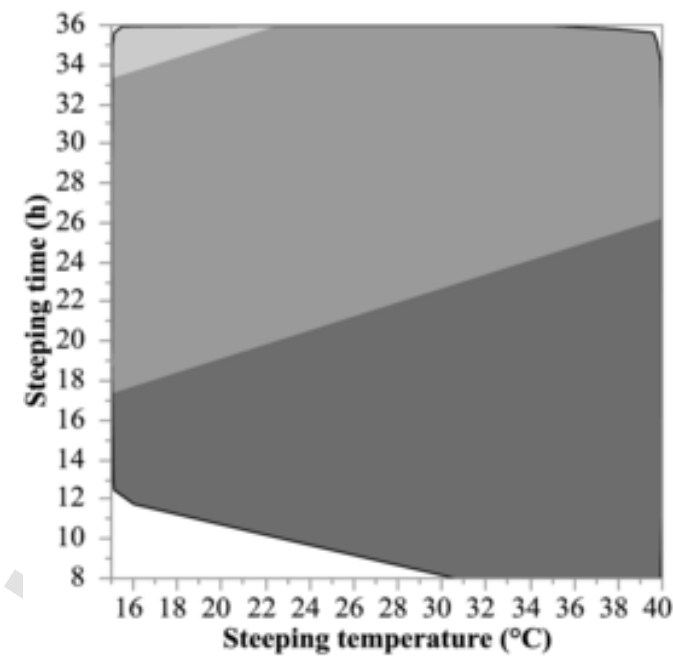

$<0.65$

$<0.71$

$<0.78$ more active at germination temperatures of $22-28^{\circ} \mathrm{C}$ than at $15^{\circ} \mathrm{C}$. However, at temperatures exceeding $30^{\circ} \mathrm{C}$ the germination capacity and rate of cereal grains decrease (Bewley et al., 2013). In addition, we noted a significant interaction between steeping and germination temperatures $(\mathrm{P}=0.006)$. For instance, when applying a steeping temperature of $15^{\circ} \mathrm{C}$ a higher germination temperature of $26^{\circ} \mathrm{C}$ was needed to substantially decrease the phytate content. However, when the grains were first subjected to steeping temperatures of about $40^{\circ} \mathrm{C}$, a lower germination temperature $\left(22^{\circ} \mathrm{C}\right)$ led to the highest phytate breakdown (Supplementary data, Fig. S2A). It is known that endogenous wheat phytase can be active during steeping at about $40-50^{\circ} \mathrm{C}$ (Lemmens et al., 2018; Sung et al., 2005). In addition, when applying low steeping temperatures, higher germination temperatures are required for substantial phytase action (Ou et al., 2011).

More specifically, using our final fitted model, a phytate content of less than $0.65 \%$ of idm was predicted after wheat steeping for at least $33 \mathrm{~h}$ at $15-22^{\circ} \mathrm{C}$ and subsequent germination at $26^{\circ} \mathrm{C}$ for $120 \mathrm{~h}$ (Fig. 1A). Similar phytate contents were reached when the grains were steeped at $15^{\circ} \mathrm{C}$ for $36 \mathrm{~h}$ and germinated for at least $100 \mathrm{~h}$ at $24-28^{\circ} \mathrm{C}$ (Fig. 1B). Overall, Fig. 1 shows that the predicted phytate content was more sensitive to the germination than to the steeping conditions.

\subsection{Impact of steeping and germination conditions of wheat grains on water extractable arabinoxylan contents}

Mineral elements are chelated to phytate and also entrapped in plant cells with rigid walls which are not hydrolysed by digestive enzymes (Balk et al., 2019). We here aimed to hydrolyse AX, and, hence, to open the plant cells as effectively as possible. The I-optimal experimental design also provided information concerning the impact of steeping and germination conditions on wheat grain AX hydrolysis (cfr. 2.2).

There was a significant positive main effect of steeping time $(\mathrm{P}<0.001)$ (Supplementary data, Fig. S2B). So, generally, relatively long steeping times $(30-36 \mathrm{~h})$ were needed to maximise the wheat WEAX contents. There was, however, also a significant interaction effect of steeping time and temperature $(\mathrm{P}=0.004)$. When applying high steeping temperatures $\left(35-40^{\circ} \mathrm{C}\right)$, the steeping time had only a mar-

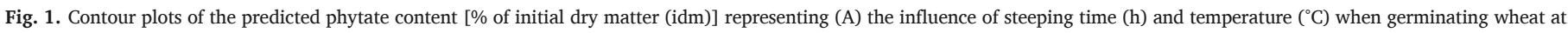

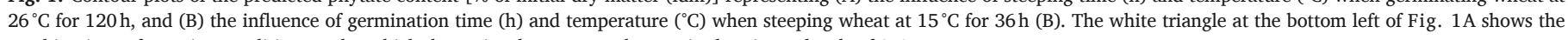
combinations of steeping conditions under which the grains do not meet the required moisture levels of $35 \%$. 
ginal impact on final WEAX contents. For low steeping temperatures, the steeping time had a very strong positive effect (Supplementary data, Fig. S2B). The final response surface model also involved a positive main effect $(\mathrm{P}<0.001)$ for steeping temperature and a significant quadratic effect for germination time $(\mathrm{P}<0.001)$ (Supplementary data, Fig. S2B). Germination times of at least $90 \mathrm{~h}$ are required to substantially hydrolyse AX populations since endoxylanase activity levels only increase after 2-3 days of germination (De Backer et al., 2010). The germination temperature had a quadratic effect $(\mathrm{P}=0.013)$ on the WEAX contents. Temperatures ranging from 23 to $28^{\circ} \mathrm{C}$ were best for AX hydrolysis (Supplementary data, Fig. S2B). It is well-known that cereal endoxylanases are optimally active at $40^{\circ} \mathrm{C}$, but at germination temperatures exceeding $30^{\circ} \mathrm{C}$, the germination percentage of wheat grains generally decreases (Briggs et al., 1986). There were also significant interaction effects between steeping temperature and germination time $(P=0.001)$, steeping and germination temperature $(\mathrm{P}=0.002)$ and steeping time and germination temperature $(\mathrm{P}=0.014)$. Regarding the first interaction effect, when applying a steeping temperature of about $40^{\circ} \mathrm{C}$ a germination time of only $85 \mathrm{~h}$ was sufficient to maximise the WEAX levels. When using a steeping temperature of $15^{\circ} \mathrm{C}$ a germination time of at least $100 \mathrm{~h}$ was needed to maximise AX breakdown (Supplementary data, Fig. S2B). Applying relatively high steeping temperatures increases the grain hydration rate and initiate endoxylanase synthesis early in the germination process (Briggs et al., 1986; Miransari and Smith, 2014).

In summary, our response surface model indicates that the WEAX content increased from $0.5 \%$ of $\mathrm{dm}$ to $1.3 \%$ of idm when the grains were steeped for at least $31 \mathrm{~h}$ at $15-27^{\circ} \mathrm{C}$ and subsequently germinated at $25^{\circ} \mathrm{C}$ for $117 \mathrm{~h}$ (Fig. 2A). Similar WEAX contents were obtained when the grains were first steeped at $15^{\circ} \mathrm{C}$ for $36 \mathrm{~h}$ and then germinated for at least $80 \mathrm{~h}$ at $18-30^{\circ} \mathrm{C}$ (Fig. 2B). From Fig. 2 it is also clear that the applied germination time is the most discriminant factor for predicting the WEAX content.
3.3. Impact of steeping, germination and hydrothermal treatment of wheat grains under optimised conditions on phytate and cell wall hydrolysis

\subsubsection{Identification of the optimal steeping and germination condition for maximal phytate and cell wall hydrolysis}

In order to increase the bio-accessibility of mineral elements in wheat grains, we aimed to hydrolyse phytate structures and at the same time open the aleurone cells. To this end, we combined the two response surface models to identify the steeping and germination condition maximising both phytate (cfr. 3.1) and AX (cfr. 3.2) hydrolysis.

The models predicted that the WEAX content increased from $0.47 \%$ of $\mathrm{dm}$ to $1.36 \pm 0.07 \%$ of idm and that the phytate content decreased from $0.96 \%$ of $\mathrm{dm}$ to $0.65 \pm 0.07 \%$ of idm when the grains where steeped at $15^{\circ} \mathrm{C}$ for $36 \mathrm{~h}$ and subsequently germinated at $26^{\circ} \mathrm{C}$ for $120 \mathrm{~h}$. These predictions were experimentally validated using three confirmatory tests in which wheat grains were steeped and germinated under this optimal condition (data not shown). Comparing the measured phytate $(0.64 \pm 0.01 \%)$ and WEAX $(1.34 \pm 0.05 \%)$ contents resulting from the confirmatory tests with those predicted by the model confirmed the validity of the optimal conditions derived from the response surface models.

To gain more insight in the effect of these processing conditions on the phytate and WEAX contents in wheat as a result of endogenous phytase and endoxylanase action during germination, we compared these responses as a function of time when using both a common condition used in malt houses, referred to as standard malting $\left(15^{\circ} \mathrm{C}, 120 \mathrm{~h}\right)$ condition and the optimal (steeping at $15^{\circ} \mathrm{C}$ for $36 \mathrm{~h}$; germinating at $26^{\circ} \mathrm{C}$ for $120 \mathrm{~h}$ ) condition identified here.

\subsubsection{Impact of germination on phytase activity and phytate concentrations in wheat grains}

The phytase activity in ungerminated wheat amounted to $1.6 \pm 0.1$ $\mu$ mole phosphate $/ \mathrm{min} / \mathrm{g} \mathrm{dm}$ (data not shown) indicating that wheat grains indeed contain endogenous phytase activity. This activity level remained largely unaffected during steeping and increased rapidly during the initial germination stages (48 h) (Fig. 3). Wheat grains also contain preformed inactive phytases which are activated within the first hours of germination (Ou et al., 2011). The further increase in

A

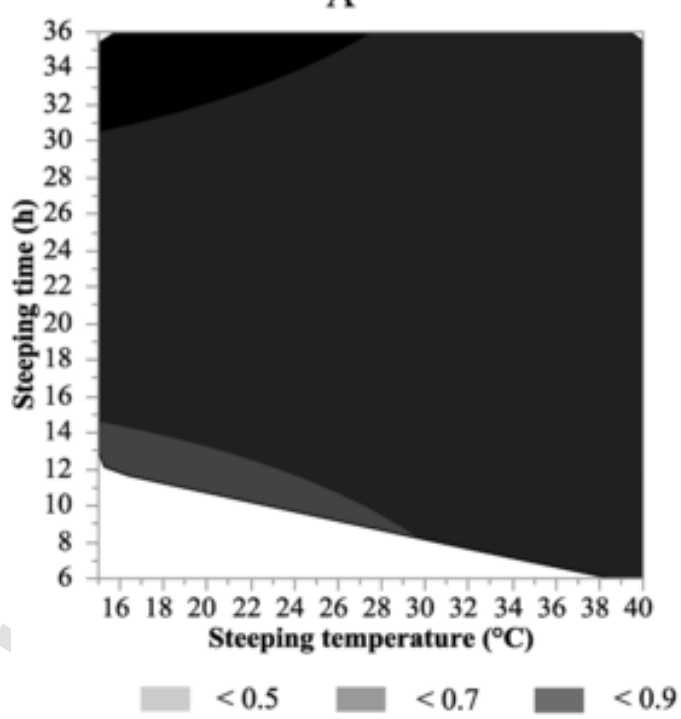

B

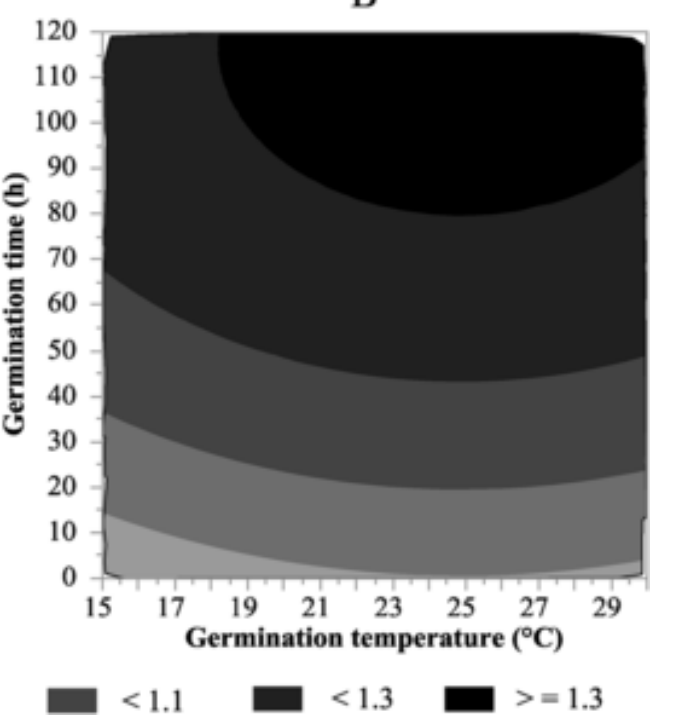

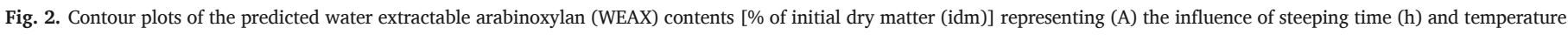

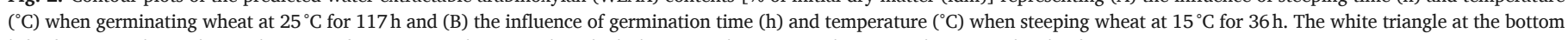
left of Fig. 2A shows the combination of steeping conditions under which the grains do not meet the required moisture levels of $35 \%$. 


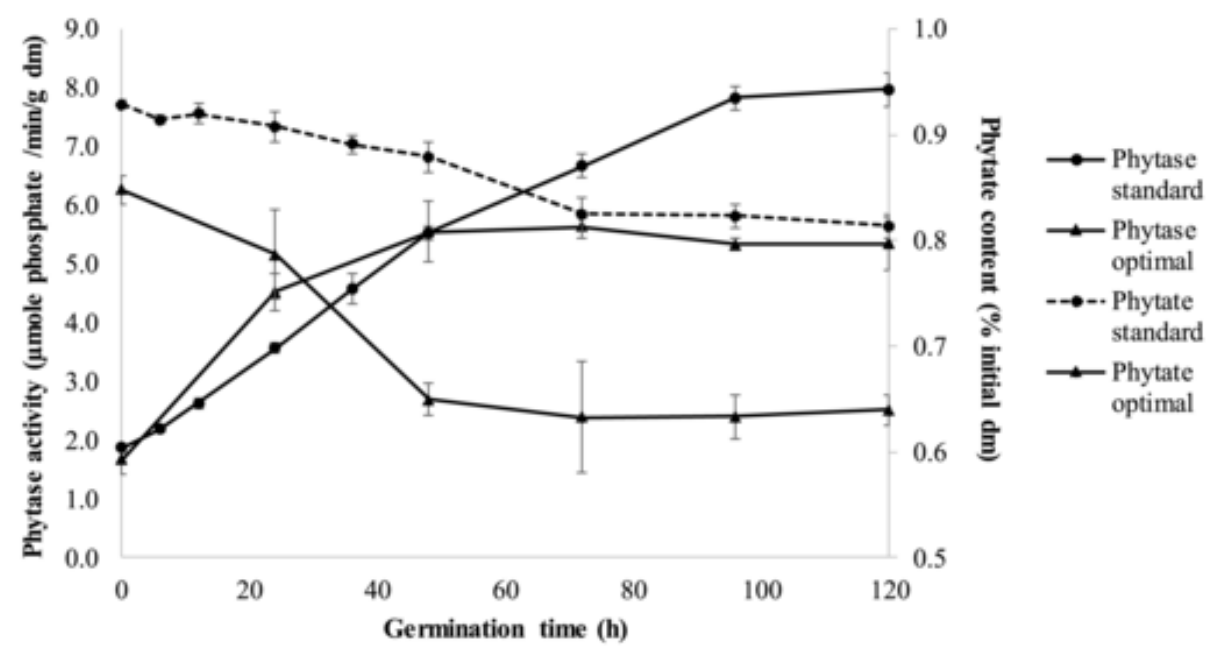

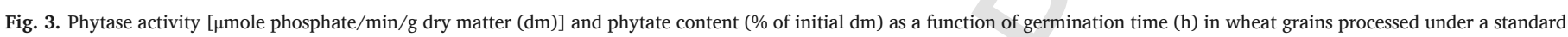

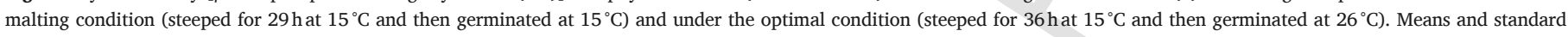
deviations of at least 3 independent (biological) replicates are given each measured with at least 3 technical repeats.

phytase activity after $12 \mathrm{~h}$ of germination is attributed to de novo synthesis of the enzyme (Sung et al., 2005). The phytase activity in wheat grains processed at the condition chosen to maximise phytate and $\mathrm{AX}$ hydrolysis increased until $48 \mathrm{~h}$ of germination after which it remained constant or even slightly decreased (Fig. 3). Indeed, it has been reported that the phytase activity decreases relatively fast (by 20-50\%) at steeping and/or germination temperatures exceeding $20^{\circ} \mathrm{C}$ (Sung et al., 2005). This decrease in enzyme activity is caused by phytase degradation by peptidases and/or by product inhibition due to the released phosphate groups (Sung et al., 2005). As a consequence, the phytase activity levels in grains processed at the optimal condition were clearly lower $(5.3 \mu$ mole phosphate $/ \mathrm{min} / \mathrm{g} \mathrm{dm})$ after $120 \mathrm{~h}$ of germination than in grains processed at a standard malting condition $(8.0 \mu$ mole phosphate/min/g dm) $(\mathrm{P}<0.05)$ (Fig. 3). Sung et al. (2005) for barley observed that maximum phytase activity level is reached after 4 days of germination at $25^{\circ} \mathrm{C}$ and amounts to $2.7 \mu$ mole phosphate $/ \mathrm{min} / \mathrm{g}$. In contrast, only after 7 days of germination at $15^{\circ} \mathrm{C}$, a maximum phytase activity of $2.9 \mu \mathrm{mole}$ phosphate $/ \mathrm{min} / \mathrm{g}$ is obtained (Sung et al., 2005).

Although we here noted a 5-fold increase in phytase activity level in wheat grains steeped and germinated at $15^{\circ} \mathrm{C}$ (i.e. standard malting condition), the phytate content only decreased from $0.96 \pm 0.01 \%$ of $\mathrm{dm}$ in ungerminated wheat (data not shown) to $0.81 \%$ of idm (Fig. 3). In contrast, steeping wheat at $15^{\circ} \mathrm{C}$ for $36 \mathrm{~h}$ and then germinating it at $26^{\circ} \mathrm{C}$ for $120 \mathrm{~h}$ (i.e. optimal condition) decreased the phytate content further to $0.64 \%$ of idm (Fig. 3). Bartnik and Szafranska (1987) observed that after 1 day of germination at $20^{\circ} \mathrm{C}$ the phytate breakdown in wheat amounts $15-18 \%$, while it is $18-24 \%$ after 4 days of germination. Similar findings have been reported with other cereals. Hübner et al. (2010a,b) reported that increasing the germination temperature from 12 to $18^{\circ} \mathrm{C}$ increased the phytate breakdown in oats from 14 to $26 \%$ after 4 days of germination. They noted an increased endogenous phytase action at temperatures closer to its optimum. The largest phytate breakdown at higher germination temperatures occurred during steeping and the initial germination stages (from $0.96 \%$ of $\mathrm{dm}$ to $0.65 \%$ of idm after $48 \mathrm{~h}$ of germination at $26^{\circ} \mathrm{C}$ ) (Fig. 3). Hübner et al. $(2010 \mathrm{a}, \mathrm{b})$ reported that the main hydrolysis of phytate in barley occurs during steeping and the first 2 days of germination. It has been reported that product inhibition due to released phosphate groups can occur and that myo-inositol groups containing only one to four phos- phate mono-ester groups are difficult to hydrolyse (Greiner et al., 2000).

3.3.3. Impact of germination on endoxylanase activity and water extractable arabinoxylan concentrations in wheat grains

The endoxylanase activity level in ungerminated wheat was $0.13 \pm 0.02 \mathrm{U} / \mathrm{h} / \mathrm{g} \mathrm{dm}$ (data not shown). The enzyme activity level decreased slightly during steeping to $0.04-0.11 \mathrm{U} / \mathrm{h} / \mathrm{g} \mathrm{dm}$ (Fig. 4) probably because exogenous microbial xylanases were washed away from the surface of the grains. It remained largely unaffected until $48 \mathrm{~h}$ of germination and then strongly increased (Fig. 4). De Backer et al. (2010) showed, using immunoblotting, that endogenous $\beta$-D-xylanase is de novo synthesised only after 6 days of germination. According to Corder and Henry (1989) the endoxylanase activity is very low during the first three days of germination, but then rapidly increases up to 30 times its initial level. In the present case, germination at $15^{\circ} \mathrm{C}$ for 5 days resulted in an endoxylanase activity level of $0.63 \mathrm{U} / \mathrm{h} / \mathrm{g} \mathrm{dm}$, while it was only $0.42 \mathrm{U} / \mathrm{h} / \mathrm{g} \mathrm{dm}(\mathrm{P}<0.05)$ when germinating at $26^{\circ} \mathrm{C}(\mathrm{Fig}$. 4). Hübner et al. (2010a,b) also found that the endoxylanase activity in rye is clearly higher when it is germinated at relatively low temperatures $\left(10-15^{\circ} \mathrm{C}\right)$.

Endoxylanase solubilises water unextractable AX (WUAX) into WEAX in the aleurone and starchy endosperm of cereals, causing structural changes in dietary fibre matrix upon germination (De Backer et al., 2010). Here, the WEAX content gradually increased from $0.48 \pm 0.04 \%$ of $\mathrm{dm}$ in ungerminated wheat (data not shown) to $0.95 \%$ of idm after 5 days of germination when applying a standard malting condition to the grains (Fig. 4). De Backer et al. (2010) also found an almost linear increase in the WEAX content in wheat from $0.38 \%$ of $\mathrm{dm}$ to $0.94 \%$ of $\mathrm{dm}$ during the first 6 days of germination at $20^{\circ} \mathrm{C}$. Here, the optimal germination condition caused the WEAX content to increase after steeping almost linearly until 3 days of germination $(1.30 \%$ of idm) and then to remain fairly constant (1.34\% of idm after 5 days of germination at $26^{\circ} \mathrm{C}$ ) (Fig. 4). Krahl et al. (2010) also observed that increasing the germination temperature from 12 to $18^{\circ} \mathrm{C}$ increases the WEAX content from $1.17 \%$ to $1.43 \%$ of $\mathrm{dm}$ in wheat germinated for 5 days.

The ara to xyl (A/X) ratio of WEAX in ungerminated wheat amounts to $0.81 \pm 0.02$ (Table 1 ), which is in line with values of $0.71-0.73$ for whole meal by Barron et al. (2007). When applying the standard 


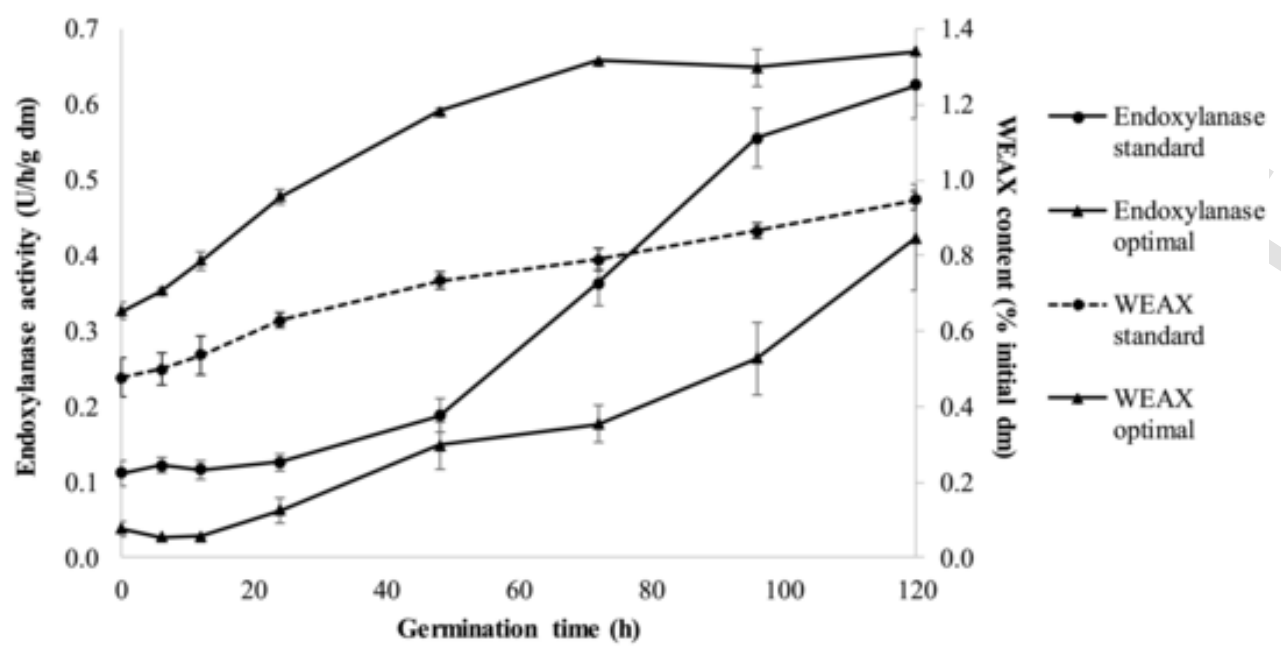

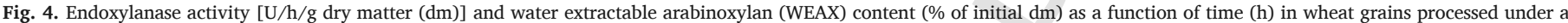

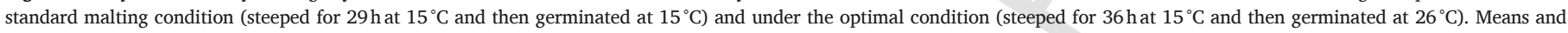
standard deviations of at least 3 independent (biological) replicates are given each measured with at least 3 technical repeats.

Table 1

Phytate content [\% of initial dry matter (idm)], water extractable arabinoxylan (WEAX) content (\% of idm), arabinose (ara) to xylose (xyl) (A/X) ratio and average degree of polymerisation (avDP) of WEAX as a result of germination $\left(26^{\circ} \mathrm{C}, 48 \mathrm{~h}\right.$ and $\left.120 \mathrm{~h}\right)$ and subsequent hydrothermal treatment $\left(40^{\circ} \mathrm{C}, 8 \mathrm{~h}\right)$. Values in the same column with a different letter are significantly different $(\mathrm{P}<0.05$, Tukey's test). Means and standard deviations of at least 3 independent (biological) replicates each measured with 3 technical repeats are given.

\begin{tabular}{|c|c|c|c|c|}
\hline & $\begin{array}{l}\text { Phytate } \\
\text { content ( } \% \text { of } \\
\text { idm) }\end{array}$ & $\begin{array}{l}\text { WEAX } \\
\text { content }(\% \text { of } \\
\text { idm) }\end{array}$ & $\mathrm{A} / \mathrm{X}$ & avDP \\
\hline Wheat & $\begin{array}{l}0.96 \pm 0.01 \\
\mathrm{a}\end{array}$ & $\begin{array}{l}0.46 \pm 0.04 \\
\mathrm{a}\end{array}$ & $\begin{array}{l}0.81 \pm 0.02 \\
\mathrm{a}\end{array}$ & $\begin{array}{l}89.8 \pm 9.8 \\
\text { a }\end{array}$ \\
\hline $\begin{array}{l}\text { Steeped } \\
\left(15^{\circ} \mathrm{C}, 36 \mathrm{~h}\right) \\
\text { and } \\
\text { germinated } \\
\left(26^{\circ} \mathrm{C}, 48 \mathrm{~h}\right) \\
\text { wheat }\end{array}$ & $0.65 \pm 0.02^{b}$ & $1.18 \pm 0.02^{b}$ & $0.64 \pm 0.01^{b}$ & $82.3 \pm 4.0$ \\
\hline $\begin{array}{l}\text { Steeped } \\
\left(15^{\circ} \mathrm{C}, 36 \mathrm{~h}\right) \\
\text { and } \\
\text { germinated } \\
\left(26^{\circ} \mathrm{C}, 120 \mathrm{~h}\right) \\
\text { wheat }\end{array}$ & $0.64 \pm 0.01^{b}$ & $\begin{array}{l}1.34 \pm 0.05 \\
\mathrm{c}\end{array}$ & $0.64 \pm 0.02^{b}$ & $45.3 \pm 2.1^{b}$ \\
\hline $\begin{array}{l}\text { Germinated } \\
\left(26^{\circ} \mathrm{C}, 48 \mathrm{~h}\right) \\
\text { and treated } \\
\left(40^{\circ} \mathrm{C}, 8 \mathrm{~h}\right) \\
\text { wheat }\end{array}$ & $\begin{array}{l}0.47 \pm 0.05 \\
c\end{array}$ & $1.10 \pm 0.04^{b}$ & $0.65 \pm 0.01^{b}$ & $\begin{array}{l}24.4 \pm 3.9 \\
c\end{array}$ \\
\hline
\end{tabular}

malting condition to wheat this ratio significantly $(\mathrm{P}<0.05)$ decreased to $0.70 \pm 0.03$ after $48 \mathrm{~h}$ of germination and then remained largely unaffected. When using the optimal condition the $\mathrm{A} / \mathrm{X}$ ratio already significantly decreased to $0.72 \pm 0.02$ after steeping and to $0.65 \pm 0.01$ after $72 \mathrm{~h}$ of germination (Table 1 ). Krahl et al. (2009) also found that the $\mathrm{A} / \mathrm{X}$ ratio of WEAX decreases from 0.74 to 0.63 during malting $\left(15^{\circ} \mathrm{C}\right.$, 6 days) of wheat. It has been suggested that the ara substituents are progressively removed by arabinofuranosidase during the growth of the seedling. However, complete hydrolysis of wheat AX is difficult due to the presence of differently linked ara or doubly substituted xyl which are not prone to degradation (Gibeaut et al., 2005).

\subsubsection{Impact of hydrothermal treatment of germinated wheat grains on} their water extractable arabinoxylan properties

In a next step, wheat grains germinated for $48 \mathrm{~h}$ at $26^{\circ} \mathrm{C}$ were hydrothermally treated for $8 \mathrm{~h}$ at $40^{\circ} \mathrm{C}$ to allow further phytase and endoxylanase action (cfr. 2.3). By doing so, the phytate content further decreased to $0.47 \%$ of idm while the WEAX content remained unchanged $(\mathrm{P}<0.05)$ (Table 1$)$. This treatment also did not significantly alter the $\mathrm{A} / \mathrm{X}$ ratio $( \pm 0.64)$ of WEAX (Table 1 ). That WUAX is not further solubilised due to endoxylanase action can be explained by the relatively high $\mathrm{A} / \mathrm{X}$ ratio of the residual WUAX population. Indeed, highly branched AX structures such as for example present in the pericarp tissue $(\mathrm{A} / \mathrm{X}>0.9)$ are inter alia not susceptible to enzymatic degradation, since most endoxylanases preferentially hydrolyse unsubstituted domains along the xylan backbone and are hindered by ara side chains (Barron et al., 2007).

Nevertheless, the avDP readings decreased from 89.8 in ungerminated wheat to 45.3 in wheat germinated for $120 \mathrm{~h}$ at $26^{\circ} \mathrm{C}$ (Table 1 ), indicating that the synthesised endoxylanases did not only solubilise $\mathrm{AX}$ but also decreased its avDP due to a random attack of the xylan backbone. In addition, the avDP did further decrease to 24.4-38.0 in hydrothermally treated germinated wheat grains (Table 1). Courtin et al. (2009) found an avDP of 99 in the aqueous extract of a commercial wheat malt, while Guo et al. (2014) reported an avDP of 13-27 of wheat malt WEAX. The synthesised endoxylanase probably further acted on the WEAX polymers as substrate to serve the seedling's need for energy and building blocks (De Backer et al., 2010).

\subsection{Impact of steeping and germination conditions of wheat grains on iron and zinc bio-accessibility}

To investigate whether phytic acid or the aleurone cells with rigid walls dominantly affect the bio-accessibility of mineral elements in wheat, we first studied the relationship between the degree of phytate breakdown and mineral bio-accessibility in whole meal. The cell walls were mechanically broken down by milling into whole meal passing a $200 \mu \mathrm{m}$ sieve prior to subjecting the study samples to an in vitro digestion protocol. The Fe and $\mathrm{Zn}$ bio-accessibility in ungerminated wheat with a phytate content of $0.96 \%$ of $\mathrm{dm}$ were 4.6 and $2.5 \%$, respectively (Table 2). A phytate breakdown to $0.88 \%$ of idm significantly in- 
Table 2

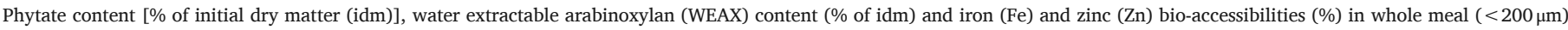

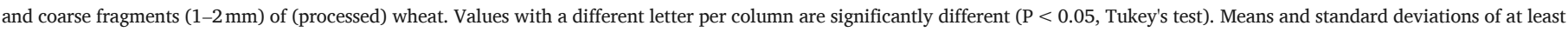
3 independent (biological) replicates each measured with 3 technical repeats are given.

\begin{tabular}{|c|c|c|c|c|c|c|}
\hline & \multicolumn{4}{|c|}{ Whole meal $(<200 \mu \mathrm{m})$} & \multicolumn{2}{|c|}{ Coarse fragments $(1-2 \mathrm{~mm})$} \\
\hline & $\begin{array}{l}\text { Phytate content }(\% \\
\text { of idm) }\end{array}$ & $\begin{array}{l}\text { Fe bio- } \\
\text { accessibility (\%) }\end{array}$ & $\begin{array}{l}\text { Zn bio- } \\
\text { accessibility (\%) }\end{array}$ & $\begin{array}{l}\text { WEAX content ( } \% \\
\text { of idm) }\end{array}$ & $\begin{array}{l}\text { Fe bio- } \\
\text { accessibility }(\%)\end{array}$ & $\begin{array}{l}\text { Zn bio- } \\
\text { accessibility (\%) }\end{array}$ \\
\hline Wheat & $0.96 \pm 0.01^{\mathrm{a}}$ & $4.6 \pm 0.3^{\mathrm{a}}$ & $2.5 \pm 0.2^{a}$ & $0.46 \pm 0.04^{\mathrm{a}}$ & $4.8 \pm 0.8^{a}$ & $5.3 \pm 0.6^{a}$ \\
\hline $\begin{array}{l}\text { Steeped }\left(33^{\circ} \mathrm{C}, 8 \mathrm{~h}\right) \text { and germinated }\left(23^{\circ} \mathrm{C} \text {, }\right. \\
120 \mathrm{~h}) \text { wheat }\end{array}$ & $0.88 \pm 0.01^{a}$ & $10.9 \pm 0.3^{b}$ & $11.8 \pm 0.2^{b}$ & $1.11 \pm 0.02^{b}$ & $4.2 \pm 0.1$ a & $7.8 \pm 0.1^{b}$ \\
\hline $\begin{array}{l}\text { Steeped }\left(15^{\circ} \mathrm{C}, 29 \mathrm{~h}\right) \text { and germinated }\left(15^{\circ} \mathrm{C} \text {, }\right. \\
120 \mathrm{~h}) \text { wheat }\end{array}$ & $0.81 \pm 0.01$ & $14.1 \pm 1.5^{b}$ & $13.9 \pm 1.4^{b}$ & $0.98 \pm 0.04^{c}$ & $5.4 \pm 0.1$ a & $8.2 \pm 0.8^{b}$ \\
\hline $\begin{array}{l}\text { Steeped }\left(15^{\circ} \mathrm{C}, 36 \mathrm{~h}\right) \text { and germinated }\left(26^{\circ} \mathrm{C} \text {, }\right. \\
120 \mathrm{~h}) \text { wheat }\end{array}$ & $0.64 \pm 0.01^{c}$ & $21.7 \pm 3.0^{\mathrm{c}}$ & $20.9 \pm 1.0^{c}$ & $1.34 \pm 0.05^{\mathrm{d}}$ & $6.8 \pm 2.4^{a}$ & $5.8 \pm 0.7^{a}$ \\
\hline $\begin{array}{l}\text { Germinated }\left(26^{\circ} \mathrm{C}, 48 \mathrm{~h}\right) \text { and treated }\left(40^{\circ} \mathrm{C} \text {, }\right. \\
8 \mathrm{~h}) \text { wheat }\end{array}$ & $0.47 \pm 0.05^{d}$ & $21.9 \pm 1.7^{c}$ & $25.3 \pm 1.0^{\mathrm{cd}}$ & $1.10 \pm 0.04^{b}$ & $7.8 \pm 1.6^{a}$ & $8.4 \pm 0.6^{b}$ \\
\hline
\end{tabular}

creased the Fe and Zn bio-accessibility to about 10.9 and $11.8 \%$, respectively. Further phytate breakdown to $0.81 \%$ of idm increased the Fe and $\mathrm{Zn}$ bio-accessibility to about $14 \%(\mathrm{P}>0.05)$. When the phytate was lowered to $0.64 \%$ of idm, the Fe and Zn bio-accessibility figures were 21.7 and $20.9 \%$, respectively (Table 2 ). In the case of sorghum Afify et al. (2011) reported that a $30 \%$ decreased phytate content as a result of germination increased the Fe and $\mathrm{Zn}$ bio-accessibilities from 10 to $20 \%$ and from 8 to $15 \%$, respectively. When hydrolysing about $50 \%$ of the phytate to a content of $0.47 \%$ of idm by hydrothermally treating germinated wheat for $8 \mathrm{~h}$ at $40^{\circ} \mathrm{C}$, the $\mathrm{Fe}$ and $\mathrm{Zn}$ bio-accessibilities were 21.9 and $25.3 \%$, respectively $(\mathrm{P}>0.05$ ) (Table 2 ). An almost completely breakdown of phytate is necessary to increase the Fe and $\mathrm{Zn}$ bio-accessibility to up to $40 \%$ as shown in Lemmens et al. (2018) and Sandberg and Svanberg (1991).

The linear relationship between phytate contents and $\mathrm{Fe}\left(\mathrm{R}^{2}=0.88\right)$ and $\mathrm{Zn}\left(\mathrm{R}^{2}=0.95\right)$ bio-accessibility (Supplementary data, Fig. S3) suggested that mineral bio-accessibility in whole meal is dictated by its chelation to phytate structures rather than by its entrapment in rigid aleurone cells. Indeed, the linear association for WEAX contents and Fe $\left(\mathrm{R}^{2}=0.58\right)$ and $\mathrm{Zn}\left(\mathrm{R}^{2}=0.59\right)$ bio-accessibility (data not shown) was substantially less strong than for phytate contents. As a note, the regressions included 12 experiments and 36 analytical measurements.

To study the impact of both phytate and cell wall hydrolysis on mineral bio-accessibility, an in vitro digestion procedure was performed on the corresponding coarse wheat fragments $(1-2 \mathrm{~mm})$ containing substantial amounts of intact (aleurone) cells. Interestingly, although up to $30-50 \%$ of the initial phytate was broken down, no significant differences $(\mathrm{P}>0.05)$ in Fe or Zn bio-accessibility was observed between ungerminated, germinated and hydrothermally treated study samples and these accessibilities amounted to only 5-8\% (Table 2). Partial hydrolysis of (aleurone) cell wall material during germination did not release the mineral elements, suggesting that they were still entrapped in these cells. As a note, dietary fibre which - by its own nature resists hydrolysis by digestive enzymes in the human small intestine - can be fermented by colonic microbiota leading to partial delivery of mineral elements. However, to date, there is no clear evidence of colonic contribution to $\mathrm{Zn}$ absorption in humans (Gopalsamy et al., 2015). Moreover, $\mathrm{Fe}$ is predominantly transported across the enterocyte brush border membrane and not absorbed in the colon (Fuqua et al., 2012).

Thus, to make minerals accessible for uptake in the human gastro-intestinal tract, it is absolutely needed to hydrolyse phytate to a large extent as well as to open up the aleurone cells.

\section{Conclusions}

Iron and $\mathrm{Zn}$ in cereals are mainly entrapped in aleurone cells with rigid walls and are chelated by phytic acid which results in their bio-accessibility amounting to typically only 5 and $3 \%$, respectively. This study aimed to maximise the hydrolysis of phytate and cell walls by using optimised wheat steeping and germination conditions. Long germination times $(>90 \mathrm{~h})$ and high temperatures $\left(23-28^{\circ} \mathrm{C}\right)$ are the most discriminant factors.

Steeping wheat for 36 hat $15^{\circ} \mathrm{C}$ and subsequent germination for 120 hat $26^{\circ} \mathrm{C}$ led to $33 \%$ phytate breakdown and a 2.8 -fold increase in the WEAX content. When hydrothermally treating germinated wheat grains for $8 \mathrm{~h}$ at $40^{\circ} \mathrm{C}$ to allow optimal enzyme action, the phytate breakdown increased to $60 \%$, while no changes in WEAX contents were observed. The latter is explained by the fact that the remainder highly branched AX structures are not susceptible to enzymatic degradation. Endoxylanase did however randomly attack the xylan backbone of WEAX, lowering its average degree of polymerisation.

As a result of the phytate hydrolysis, Fe bio-accessibility increased from 5 to $22 \%$ and $\mathrm{Zn}$ bio-accessibility from 3 to $25 \%$ in whole meal. However, when not mechanically opening the aleurone cell walls, no significant changes in Fe and Zn bio-accessibility were observed. Thus, partial hydrolysis of the cell walls during germination did not suffice for releasing the mineral elements. Therefore, controlled steeping and germination can substantially increase the content of bio-accessible mineral elements in wheat provided that cell walls are mechanically broken.

\section{Acknowledgements}

This research was conducted in the framework of the W.K. Kellogg Chair in Cereal Science and Nutrition at the KU Leuven (chair holders J.A. Delcour and K. Verbeke) and is part of the Methusalem program "Food for the Future" (2007-2021). Fruitful discussions with Drs. N. Almeida, K. Spence, K Greaves, L. Sanders and E. Michalski (Kellogg Company, Battle Creek, MI, USA) are highly appreciated.

\section{Appendix A. Supplementary data}

Supplementary data to this article can be found online at https://doi. org/10.1016/j.jcs.2019.102847.

\section{Conflicts of interest}

The authors declare that they do not have any conflict of interest. 


\section{References}

Afify, A.E.M.R., El-Beltagi, H.S., El-Salam, S.M.A., Omran, A.A., 2011. Bioavailability of iron, zinc, phytate and phytase activity during soaking and germination of white sorghum varieties. PLoS One 6, 1-7.

Balk, J., Connorton, J.M., Wan, Y., Lovegrove, A., Moore, K.L., Uauy, C., Sharp, P.A., Shewry, P.R., 2019. Improving wheat as a source of iron and zinc for global nutrition. Nutr. Bull. 44, 53-59.

Barron, C., Surget, A., Rouau, X., 2007. Relative amounts of tissues in mature wheat (Triticum aestivum L.) grain and their carbohydrate and phenolic acid composition. J. Cereal Sci. 45, 88-96.

Bartnik, M., Szafranska, I., 1987. Changes in phytate content and phytase activity during the germination of some cereals. J. Cereal Sci. 5, 23-28.

Bewley, J.D., Bradford, K.J., Hilhorst, H.W.M., Nonogaki, H., 2013. Seeds: Physiology of Development, Germination and Dormancy. Springer, New York, USA, p. 399.

Briggs, D.E., Hough, J.S., Sevens, R., Young, T.W., 1986. Malting and Brewing Science. In: Malt and Sweet Wort, ume 1. Chapman and Hall, USA, New York, p. 354.

Corder, A.M., Henry, R.J., 1989. Carbohydrate-degrading enzymes in germinating wheat. Cereal Chem. 66, 435-439.

Courtin, C.M., Broekaert, W.F., Swennen, K., Aerts, G., Van Craeyveld, V., Delcour, J.A., 2009. Occurrence of arabinoxylo-oligosaccharides and arabinogalactan peptides in beer. J. Am. Soc. Brew. Chem. 67, 112-117.

De Backer, E., Gebruers, K., Van den Ende, W., Courtin, C.M., Delcour, J.A., 2010. Post-translational processing of $\beta$-D-xylanases and changes in extractability of arabinoxylans during wheat germination. Plant Physiol. Biochem. 48, 90-97.

de Munter, J.S.L., Hu, F.B., Spiegelman, D., Franz, M., van Dam, R.M., 2007. Whole grain, bran, and germ intake and risk of type 2 diabetes: a prospective cohort study and systematic review. PLoS Med. 4, 1385-1395.

Delcour, J.A., Hoseney, R.C., 2010. Principles of Cereal Science and Technology. third ed. AACC International, St. Paul, MN, USA, p. 270.

Fardet, A., 2010. New hypotheses for the health-protective mechanisms of whole-grain cereals: what is beyond fibre. Nutr. Res. Rev. 23, 65-134.

Fuqua, B.K., Vulpe, C.D., Anderson, G.J., 2012. Intestinal iron absorption. J. Trace Elem. Med. Biol. 26, 115-119.

Gibeaut, D.M., Pauly, M., Bacic, A., Fincher, G.B., 2005. Changes in cell wall polysaccharides in developing barley (Hordeum vulgare) coleoptiles. Planta 221, 729-738.

González-Córdova, A.F., Beltrán-Barrientos, L.M., Santiago-López, L., Garcia, H.S., Vallejo-Cordoba, B., Hernandez-Mendoza, A., 2016. Phytate-degrading activity of probiotic bacteria exposed to simulated gastrointestinal fluids. LWT - Food Sci. Technol. 73, 67-73.

Gopalsamy, G.L., Alpers, D.H., Binder, H.J., Tran, C.D., Ramakrishna, B.S., Brown, I., Manary, M., Mortimer, E., Young, G.P., 2015. The relevance of the colon to zinc nutrition. Nutrients 7, 572-583.
Greiner, R., Jany, K., Alminger, M.L., 2000. Identification and properties of myo-inositol hexakisphosphate phosphohydrolases (phytases) from barley (Hordeum vulgare). J. Cereal Sci. 31, 127-139.

Guo, M., Du, J., Zhang, K., Jin, Y., 2014. Content and molecular weight of water-extractable arabinoxylans in wheat malt and wheat malt-based wort with different Kolbach indices. J. Sci. Food Agric. 94, 2794-2800.

Hübner, F., O'Neil, T., Cashman, K.D., Arendt, E.K., 2010. The influence of germination conditions on beta-glucan, dietary fibre and phytate during germination of oats and barley. Eur. Food Res. Technol. 231, 27-35.

Hübner, F., Schehl, B.D., Gebruers, K., Courtin, C.M., Delcour, J.A., Arendt, E.K., 2010. Influence of germination time and temperature on the properties of rye malt and rye malt based worts. J. Cereal Sci. 52, 72-79.

Krahl, M., Müller, S., Zarnkow, M., Back, W., Becker, T., 2009. Arabinoxylan and fructan in the malting and brewing process. Qual. Assur. Saf. Crop. Foods 1, 246-255.

Krahl, M., Zarnkow, M., Back, W., Becker, T., 2010. Determination of the influence of malting parameters on the water-extractable arabinoxylan content of wheat (Triticum aestivum), rye (Secale cereale), and spelt wheat (Triticum aestivum spp. spelta). J. Am. Soc. Brew. Chem. 68, 34-40.

Lemmens, E., De Brier, N., Spiers, K.M., Ryan, C.G., Garrevoet, J., Falkenberg, G., Goos, P., Smolders, E., Delcour, J.A., 2018. The impact of steeping, germination and hydrothermal processing of wheat (Triticum aestivum L.) grains on phytate hydrolysis and the distribution, speciation and bio-accessibility of iron and zinc elements. Food Chem. 264, 367-376.

Lemmens, E., Moroni, A.V., Pagand, J., Heirbaut, P., Ritala, A., Karlen, Y., Lê, K., Van den Broeck, H.C., Brouns, F.J.P.H., De Brier, N., Delcour, J.A., 2019. Impact of cereal seed sprouting on its nutritional and technological properties: a critical review. Compr. Rev. Food Sci. Food Saf. 18, 305-328.

Miransari, M., Smith, D.L., 2014. Plant hormones and seed germination. Environ. Exp. Bot. 99, 110-121.

Ou, K., Cheng, Y., Xing, Y., Lin, L., Nout, R., Liang, J., 2011. Phytase activity in brown rice during steeping and sprouting. J. Food Sci. Technol. 48, 598-603.

Raboy, V., 2003. myo-Inositol-1,2,3,4,5,6-hexakisphosphate. Phytochemistry 64, 1033-1043.

Sandberg, A., Svanberg, U., 1991. Phytate hydrolysis by phytase in cereals; Effects on in vitro estimation of iron availability. J. Food Sci. 56, 1330-1333.

Shewry, P.R., Hey, S.J., 2015. The contribution of wheat to human diet and health. Food Energy Secur. 4, 178-202.

Sung, H.G., Shin, H.T., Ha, J.K., Lai, H.L., Cheng, K.J., Lee, J.H., 2005. Effect of germination temperature on characteristics of phytase production from barley. Bioresour. Technol. 96, 1297-1303. 